\title{
PENERAPAN MODEL PEMBELAJARAN PROBLEM BASED LEARNING UNTUK MENINGKATKAN KEMAMPUAN MENULIS TEKS EKSPOSISIPADA KELAS X-IPS 2
}

\author{
Immanuel D. B. Silitonga ${ }^{1}$, Dosma J. F. Sirait ${ }^{2}$ \\ *1 Penulis 1 \\ *2 Penulis 2 \\ Program Studi Pendidikan Bahasa Indonesia, fakultas keguruan dan Ilmu Pendidikan, Universitas \\ Katolik Santo Thomas, Jl. Setia Budi No.479-F Tanjung Sari Medan-Kode Pos No. 20132, \\ immanuel814@gmail.com, siraitdosma@gmail.com
}

\begin{abstract}
Abstrak
Penelitian ini merupakan penelitian PTK yang dilatarbelakangi oleh banyaknya siswa yang tidak mampu menulis teks eksposisi. Hal ini ditunjukkan dari hasil yang diperoleh oleh siswa. Berdasarkan hasil refleksi awal di kelas X-IPS 2 SMA NEGERI 1 LUMBAN JULU selama ini siswanya masih kurang aktif, dan hasil belajar di kelas X-IPS 2 pada tahun pelajaran 2019/2020 menunjukkan bahwa 67,85\% siswa belum mencapai nilai Kriteria Ketuntasan Minimal (KKM) yaitu nilai 65. Oleh karena itu, diperlukan upaya untuk meningkatkan kualitas pembelajaran Bahasa Indonesia dengan dilaksanakan penelitian tindakan kelas dengan penerapan model pembelajaran Problem Based Learning. Penelitian ini adalah penelitian tindakan kelas yang terdiri dari 2 siklus. Setiap siklus terdiri dari 2 pertemuan dengan tahapan perencanaan, pelaksanaan tindakan, observasi dan refleksi. Subjek penelitian ini adalah siswa kelas X-IPS 2 SMA NEGERI 1 LUMBAN JULU yang berjumlah 28 siswa. Teknik pengumpulan data dalam penelitian ini meliputi observasi, dokumentasi, catatan lapangan, dan tes. Teknik analisis data dengan cara analisis kualitatif dan kuantitatif. Berdasarkan penelitian yang telah dilakukan dapat diambil simpulan sebagai berikut: (1) hasil belajar siswa sebelum penerapan model pembelajaran Problem Based Learning pada materi menulis teks eksposisi tergolong rendah, terbukti dari data tes awal yang diperoleh siswa yaitu: nilai rata-rata tes awal siswa 58,39 dengan persentase ketuntasan belajar klasikal $32,14 \%$ jauh di bawah syarat minimal yaitu sebesar $85 \%$; dan (2) hasil belajar siswa mengalami peningkatan setelah diterapkan model pembelajaran Problem Based Learning pada materi menulis teks eksposisi. Dapat dilihat dari data hasil belajar pada siklus I, nilai rata-rata siswa meningkat menjadi 68,75 dengan persentase ketuntasan belajar klasikal 53,57\%, sementara pada siklus II nilai rata-rata siswa meningkat menjadi 86,07 dengan persentase ketuntasan belajar klasikal 100\%
\end{abstract}

\section{Kata kunci: Penelitian Tindakan kelas, Problem Based Learning, Kemampuan Menulis dan Teks Eksposisi}

Abstract

This research is a CAR research that is motivated by the large number of students who are unable to write exposition texts. This is shown from the results obtained by students. Based on the results of the initial reflection in class X-IPS 2 SMA NEGERI 1 LUMBAN JULU so far the students are still less active, and learning outcomes in class X-IPS 2 in the 2019/2020 school year show that $67.85 \%$ of students have not reached the value of the Minimum Completeness Criteria (KKM), which is a value of 65 . Therefore, efforts are needed to improve the quality of Indonesian Language learning by carrying out classroom action research by applying the Problem Based Learning learning model. This research is a classroom action research study consisting of 2 cycles. Each cycle consists of 2 meetings with the stages of planning,

ISSN 15421-71667

Volume 2 Nomor 2 Desember 2019 
implementing actions, observing and reflecting. The subjects of this study were students of class X-IPS 2 of SMA NEGERI 1 LUMBAN JULU, totaling 28 students. Data collection techniques in this study include observation, documentation, field notes, and tests. Data analysis techniques by means of qualitative and quantitative analysis. Based on the research that has been done, the following conclusions can be drawn: (1) student learning outcomes before the application of the Problem Based Learning learning model in writing exposition text material is classified as low, as evidenced from the initial test data obtained by students, namely: the average value of the student's initial test 58,39 with the percentage of classical learning completeness $32.14 \%$ far below the minimum requirements of $85 \%$; and (2) student learning outcomes have improved after applying the Problem Based Learning learning model to the exposition text writing material. Can be seen from the learning outcomes data in the first cycle, the average value of students increased to 68.75 with the percentage of classical learning completeness $53.57 \%$, while in the second cycle the average value of students increased to 86.07 with the percentage of classical learning completeness $100 \%$

\section{Keywords: Classroom Action Research, Problem Based Learning, Writing Ability and Exposition Text}

\section{PENDAHULUAN}

Pembelajaran bahasa Indonesi diarahkan untuk meningkatkan kemampuan berkomunikasi peserta didik dalam bahasa Indonesia dengan baik dan benar, baik secara lisan maupun tulis. Berkaitan dengan itu, Tarigan (2008:1) mengatakan, bahwa keterampilan berbahasa mencangkup empat aspek, yaitu keterampilan menyimak, keterampilan bericara, keterampilan membaca, dan keterampilan menulis. Salah satu pembelajaran menulis yang diajarkan di sekolah adalah pembelajaran menulis eksposisi. Pada umumnya, menulis dianggap sebagai suatu keterampilan berbahasa yang sangat sulit dan dijadikan beban oleh siswa, menurut Wisnu Nugroho (2016:35) kesulitan ini disebabkan oleh faktor psikologis dan metodologis. Secara psikologis, kebanyakan siswa menganggap bahwa kegiatan menulis sebagai beban karena merasa kurang mampu menggunakan bahasa Indonesia dengan baik dan benar. Secara metodologis, guru umumnya kurang bervariasi dalam memilih metode yang digunakan. Hal itu tidaklah berlebihan karena menulis merupakan sebuah kegiatan yang kompleks. Kendala lain adalah kurang mampunya siswa mengunakan bahasa Indonesia dengan baik dan benar sesuai dengan kaidah ejaan yang disempurnakan. Eksposisi adalah jenis teks

ISSN 15421-71667

Volume 2 Nomor 2 Desember 2019 yang berfungsi untuk mengungkapkan gagasan atau mengusulkan sesuatu berdasarkan argumentasi yang kuat. Teks ini berbeda dengan teks diskusi yang berisi dua sisi argumentasi; teks eksposisi hanya berisi satu sisi argumentasi: sisi yang mendukung atau sisi yang menolak. Tesis adalah inti sebuah eksposisi juga keseluruhan eksposisi itu. Maksudnya, seluruh wacana itu harus sejalan dan mendukung tesis. Tesis ini harus diikuti oleh uraian-uraian pembuktian, Marahimin menjelaskan bahwa uraian yang mendukung atau membuktikan kebenaran tesis ini biasanya disebut kelas-kelas. Urhalina (2018:1028) menyebutkan bahwa eksposisi dibangun atas tesis, kelas dan kesimpulan. Kelas ini haruslah berdasakan pembuktian dan dilakukan minimal ada tiga kali pembuktian. Dengan demikian, sebuah eksposisi sederhana dibangun atas lima paragraph yakni, paragraph tesis, tiga paragraf kelas atau pembuktian dan paragraf kesimpulan.Pengertian senada juga disampaikan oleh Samsudin (2012), bahwa eksposisi adalah karangan yang berfungsi untuk memberitahukan, memaparkan,menguraikan atau menerangkan sesuatu kepada audien tertentu. Jadi pada dasarnya, eksposisi adalah tulisan yang berusaha untuk menjelaskan suatu prosedur atau proses, memberikan definisi, menerangkan, menjelaskan, menafsirkan gagasan, 
menerangkan bagan atau tabel, mengulas sesuatu. kegiata ini dinamakan berpikir kritis. sejalan dengan pemaparan diatas, penliti mengaitkan materi pembelajaran menulis tesk eksposisi dengan model pembelajaran base learnig, diharapkan mahasiswa memngembangkan kemampuan berpikir kritis untuk menuliskan teks eksposisi.

Model pembelajaran Problem Based Learning adalah mengembangkan kemampuan siswa untuk berpikir kritis. Siswa tidak terpaku pada pembelajaran yang diberikan oleh guru. Salah satu karakteristik model pembelajaran Problem Based Learning adalah memastikan bahwa masalah yang diberikan berhubungan dengan dunia nyata siswa. Selain itu, karakteristik lain dari model pembelajaran Problem Based Learning adalah proses pembelajaran yang dilakukan dengan menggunakan kelompok kecil (Setyorini dkk 2011:54). Berdasarkan hasil observasi, terlihat sebagian besar siswa memiliki kecenderungan berkelompok saat pembelajaran berlangsung meskipun guru tidak menginstruksikan siswa untuk belajar dalam kelompok. Dalam kelompok tersebut, siswa cenderung aktif melakukan diskusi meskipun terkadang diskusi mereka tidak berkaitan dengan materi pembelajaran. Dalam hal ini, kelompok yang dibentuk siswa tersebut dapat dikatakan sebagai kondisi lingkungan sosial yang meliputi kelompok belajar. Namun dengan melihat hal tersebut, peneliti ingin memanfaatkan karakteristik yang dimiliki siswa tersebut agar sikap dan pembicaraan siswa semakin terarah dan bermanfaat dalam pembelajaran dengan cara mengarahkan siswa untuk berdiskusi dalam kelompok kecil saat pembelajaran berlangsung. Tentunya, siswa berdiskusi mengenai permasalahan yang berkaitan dengan materi pembelajaran. Dengan begitu, motivasi belajar siswa akan

\section{ISSN 15421-71667}

\section{Volume 2 Nomor 2 Desember 2019}

menjadi lebih baik karena kondisi lingkungan sosial yang mendukung siswa dalam pembelajaran. Berdasarkan paparan di atas timbul keingintahuan yang lebih banyak tentang penerapan pendekatan pembelajaran khususnya pendekatan pembelajaran yang digunakan dalam pembelajaran Menulis Teks Eksposisi. Sehingga menjadi sebuah judul yang berbunyi "Penerapan Model Pembelajaran Problem Based Learning Untuk Meningkatkan Kemampuan Menulis Teks Eksposisi Pada Kelas XIPS 2 SMA Negeri 1 Lumban Julu T.P 2019/2020

\section{PEMBAHASAN \\ Kondisi Awal Pra Siklus}

Pra Siklus merupakan kondisi awal sebelum menerapkan model yang dianjurkan. Pada tahap ini, untuk mengetahui permasalahan dilakukan obeservasi pengajaran di kelas dan memberikan tes awal kepada subyek penelitian yaitu Kelas X-IPS 2 SMA Negeri 1 Lumban Julu yang berjumlah 28 orang. Tes awal ini bertujuan untuk mengetahui kemampuan awal siswa, menentukan kelompok, dan kesulitankesulitan yang dialami siswa dalam menulis teks eksposisi.

Dari data yang diperoleh setelah melakukan tes awal disimpulkan bahwa kemampuan menulis teks eksposisi siswa sangat tidak memuaskan. Hasil yang diperoleh dari tes awal dengan nilai rataratanya yaitu 58,39 dengan rincian nilai; 9 siswa $(32,14 \%)$ orang memperoleh nilai tuntas diatas nilai KKM dan 19 siswa $(67,85 \%)$ orang belum mendapat ketuntasan nilai KKM. Dari seluruh siswa ada 2 orang siswa yang memperoleh nilai $\geq 80$ yang termasuk kategori siswa dengan tingkat penguasan sangat baik; 6 siswa memperoleh nilai 66-80 yang termasuk kategori baik; 7 siswa memperoleh nilai 51-65 yang termasuk kategori cukup; dan 13 siswa memperoleh nilai $\leq 40$ yang termasuk kategori kurang. 


\section{Pelaksanaan Siklus 1}

\section{Tahap Perencanaan}

Sesuai dengan masalah yang ditemukan di atas maka dirancang alternatif pemecahan masalah yang juga merupakan perencanaan tindakan, yaitu:

(a) peneliti dan guru merencanakan skenario pembelajaran dengan model pembelajaran Problem Based Learning;

(b) peneliti dan guru mempersiapkan instrumen tes kemampuan siswa;

(c) peneliti dan guru mempersiapkan format wawancara;

(d) guru mempersiapkan lembar observasi untuk mengamati guru dan siswa selama proses pembelajaran.

\section{Tahap Pelaksanaan}

Pelaksanaan tindakan adalah melaksanakan kegiatan belajar mengajar sesuai dengan rencana yang telah disusun. Peneliti bertindak sebagai pengamat dan guru sebagai pelaksana pembelajaran di kelas. Pembelajaran dilakukan dengan menerapkan model pembelajaran Problem Based Learning dengan materi menulis teks eksposisi. Kegiatan yang dilakukan pada tahap ini adalah: (a) membagi siswa ke dalam kelompok belajar untuk mengefektifkan pembelajaran dan menerangkan maksud dan tujuan belajar bersama; (b) guru menerangkan materi pelajaran secara garis besar kepada siswa; (c) guru dan siswa melakukan tanya jawab secara singkat tentang materi pelajaran yang disampaikan; (d) guru menyuruh siswa membuka halaman buku untuk dibahas dalam kelompok diskusi; (e) guru mengawasi kegiatan diskusi yang dilakukan siswa; (f) guru memberikan tugas akhir kepada siswa untuk mengetahui sejauhmana siswa telah menguasai materi pelajaran yang didiskusikan yang bersama kelompoknya; (g) guru memberikan penilaian terhadap tugas kelompok yang dilakukan siswa; dan (h) guru memberikan tes kepada siswa sebagai akhir dari pembelajaran siklus I.

\section{Tahap observasi}

Pada saat pelaksanaan tindakan peneliti mengamati keadaan siswa selama proses pembelajaran. Hasil observasi yang diperoleh adalah sebagai berikut:

(1) sebagian kelompok belum mengerti langkah apa yang harus dilakukan untuk mulai diskusi;

(2) ada kelompok yang anggotanya tidak berinteraksi dengan baik, sebagian siswa pasif dan tidak berpartisipasi dalam kelompoknya;

(3) ada siswa yang ragu-ragu menyelesaikan pekerjaannya dan selalu bertanya pada guru saat melaksanaan tugasnya di kelompok;

(4) wakil kelompok yang diminta menyajikan hasil pekerjaannya masih ragu- ragu dan tidak maksimal;

(5) pada saat presentasi hasil diskusi banyak siswa yang kurang memperhatikan sehingga mengganggu proses pembelajaran; dan

(6) siswa kurang percaya diri dalam mengemukakan pendapat, sehingga tidak ada tanggapan, komentar atau saran dari kelompok lain saat penyajian hasil akhir.

\section{Observasi Hasil Belajar}

Berdasarkan hasil observasi pada siklus I, pengamatan terhadap proses pembelajaran siswa diperoleh persentase keaktifan siswa sebesar $65 \%$. Berdasarkan hasil tes kemampuan menyelesaikan soalsoal untuk siklus I, diperoleh bahwa kemampuan siswa dalam menulis teks eksposisi meningkat sebeasar 21,43\% jika dibandingkan dengan hasil tes awal. Dari 
hasil tes kemampuan pada siklus I ini diperoleh nilai rata-rata 68,75 dengan dengan rincian perolehan nilai 15 dari 28 siswa $(53,57 \%)$ telah mencapai ketuntasan belajar dengan nilai $\geq 65$, sedangkan 13 siswa lainnya $(46,42 \%)$ belum tuntas. Dari 28 siswa terdapat 6 siswa memperoleh nilai $\geq 80$ termasuk siswa dengan tingkat penguasaan sangat baik; 8 siswa memperoleh nilai antara 66-80 yang termasuk siswa dengan tingkat penguasaan baik; 11 siswa memperoleh nilai antara 5165 yang termasuk siswa dengan kemampuan cukup; dan 3 siswa memperoleh nilai $\leq 49$ yang termasuk siswa dengan tingkat penguasaan kurang.

\section{Observasi Aktivitas Peneliti (Guru)}

Tahap observasi dilakukan bersamaan dengan pelaksanaan tindakan. Pada tahap ini peneliti pertama bertindak sebagai pengamat dan peneliti kedua (guru) sebagai pengajar. Dari hasil observasi inilah peneliti akan mengambil keputusan bagi tindakan selanjutnya. Observasi pada penelitian ini dilakukan pada tiap pelaksanaan tindakan. Hal-hal yang diobservasi pada pelaksanaan tindakan ini adalah cara peneliti kedua menyajikan materi pelajaran apakah sudah sesuai dengan skenario pembelajaran yang telah dirancang atau belum. Selain itu juga dilihat aktivitas siswa dalam mengikuti pembelajaran. Pengamatan ini dilakukan dengan pedoman pengamatan yang telah disediakan oleh peneliti. Jika hal-hal penting yang terjadi dalam kegiatan pembelajaran dan tidak ada dalam pedoman pengamatan, maka hal tersebut dimasukkan sebagai hasil catatan lapangan (temuan). Dalam observasi ini peneliti membagi format observasi menjadi 2 bagian yaitu lembar observer kegiatan peneliti kedua (guru) dan lembar observer kegiatan siswa. Dari hasil analisis tersebut dapat diketahui bahwa secara umum kegiatan peneliti sudah sesuai dengan rencana yang ditetapkan, namun masih ada yang belum ditetapkan. Nilai yang ISSN 15421-71667

Volume 2 Nomor 2 Desember 2019 diperoleh dari pengamatan tentang aktivitas penliti kedua (guru) adalah 30, sedangkan skor maksimal adalah 40 . Sehingga persentase nilai rata-rata adalah $75, \%$, dalam kategori baik.

\section{Observasi Aktivitas Siswa}

Berdasarkan hasil observasi dalam siklus ini dapat dilihat bahwa secara umum kegiatan sudah sesuai dengan harapan yang di capai meskipun masih ada beberapa deskriptor yang tidak muncul dalam aktivitas peserta didik selama pembelajaran. Nilai yang diperoleh dari aktivitas peserta didik yaitu 35 , sedangkan skor maksimal adalah 50 sehingga nilai yang diperoleh rata-rata adalah $70 \%$ sesuai kategori keberhasilan yang telah ditetapkan, maka keberhasilan aktivitas siswa berada pada kategori yang baik.

\section{Tahap Refleksi}

Berdasarkan hasil observasi, wawancara, dan data yang diperoleh dari tes siklus I, berikut diuraikan keberhasilan dan kegagalan dalam pelaksanaan tindakan pada siklus I, yaitu:

(1) pembentukan kelompok berdasarkan penyebaran kemampuan kelompok kurang efektif karena ada beberapa siswa yang tidak berpartisipasi aktif;

(2) ada kelompok yang terlihat tidak antusias mengerjakan soal-soal, dan tidak berdiskusi dengan baik;

(3) beberapa siswa belum memahami materi teks eksposisi sehingga mengalami kesulitan dalam diskusi kelompoknya;

(4) perwakilan kelompok yang menyajikan hasil diskusi masih belum terampil menjelaskan hasil kerja kelompoknya di depan kelas.

Masih banyak kesalahan yang dilakukan siswa dalam menulis teks eksposisi. Selain beberapa kesalahan yang ditemukan selama pembelajaran, diperoleh juga peningkatan kualitas proses 
pembelajaran menulis teks eksposisi setelah diterapkan model pembelajaran Problem Based Learning Peningkatan kualittas proses pembelajaran siswa mengalami kenaikan sebesar $21,43 \%$ (nilai klasikal kelas). Berdasarkan pemaparan data tersebut yang menunjukkan ketuntasan pembelajaran belum tercapai maka harus dilaksanakan perbaikan pembelajaran. Oleh karena itu pembelajaran dilanjutkan ke siklus II.

\section{Pelaksanaan Siklus II}

Untuk memperbaiki keurangan yang di dapat dan meningkatkan keberhasilan yang telah dicapai pada siklus I, maka direncanakan pelaksanaan siklus II sebagai berikut:

(a) Guru harus mampu meningkatkan pengelolaan kegiatan pembelajaran;

(b) guru harus memotivasi siswa agar mampu berpartisipasi lebih aktif dalam kelompok dan lebih berani menyampaikan ide dan pendapat;

(c) guru harus lebih membimbing siswa dan kelompok agar mampu menyelesaikan tugas dan menyajikan hasil diskusi dengan baik.

\section{Tahap Perencanaan}

Peneliti pertama dan kedua membuat perencanaan tindakan II untuk mengatasi kekurangan dan kegagalan pembelajaran selama siklus I. Pada tahap ini rencana tindakan yang akan dilakukan yaitu:

(a) menyusun/merancang ulang RPP dengan materi menulis teks eksposisi yang disusun dengan memperhatikan refleksi siklus I;

(b) guru menyusun kembali media sebagai bahan rangsangan instrument tes menulis II;

(c) guru mempersiapkan format wawancara;

(d) guru mempersiapkan lembar observasi guru dan siswa untuk

ISSN 15421-71667

Volume 2 Nomor 2 Desember 2019 mengamati keadaan siswa selama pembelajaran;

(e) membentuk kelompok siswa yang sama seperti pertemuan sebelumnya;

(f) guru lebih memotivasi siswa agar berpartisipasi aktif dalam diskusi; dan

(g) guru membimbing siswa agar bekerjasama dengan baik dalam kelompok agar mampu menyelesaikan tugas dan menyajikan hasil diskusi dengan lebih baik.

Tahap Pelaksanaan

Pembelajaran pada tahap ini dilakukan dengan model pembelajaran Problem Based Learning dan materi yang diajarkan adalah Harmonisasi menulis teks eksposisi. Adapun tahapan kegiatan yang dilaksanakan adalah sebagai berikut:

(1) membentuk kelompok diskusi yang terdiri dari beberapa kelompok, setiap kelompok terdiri dari 4 orang dan melakukan apersepsi;

(2) setelah siswa berdiskusi pada kelompok asal tiap-tiap anggota membentuk kelompok ahli yang tiap kelompok terdiri dari satu anggota kelompok asal dan mendiskusikan materi masing masing di kelompok ahli;

(3) setelah berdiskusi dikelompok ahli setiap siswa kembali kekelompok asal dan mendiskusikan setiap materi yang mereka peroleh dan membuat simpulan;

(4) guru dan siswa melakukan tanya jawab secara singkat tentang materi pelajaran yang disampaikan;

(5) guru memberikan kembali wacana untuk dibaca dan dibahas dalam kelompok diskusi;

(6) guru mengawasi kegiatan diskusi yang dilakukan siswa; dan 
(7) guru menyuruh masing-masing kelompok untuk melaporkan hasil diskusinya secara tertulis kepada guru untuk dibahas.

\section{Tahap observasi}

Pada pelaksanaan tindakan II guru mengamati keadaan siswa selama pembelajaran dengan model pembelajaran Problem Based Learning sebagai upaya untuk meningkatkan kemampuan menulis teks eksposisi siswa. Dari pengamatan ini diperoleh temuan sebagai berikut:

(1) terjalin kekompakan antar anggota kelompok, terlihat dengan adanya pembagian tugas dalam menyelesaikan masalah dan tiap siswa berpartisipasi aktif;

(2) suasana kelas selama kegiatan pembelajaran lebih tertib dan terkendali. Tiap siswa antusias berdiskusi dan menyelesaikan tugas kelompok;

(3) siswa lebih termotivasi untuk menyampaikan ide dan bertukar pendapat untuk saling bertukar pengetahuan; dan

(4) siswa mulai berani menyampaikan pendapat, bertanya, dan memberikan sanggahan atau tanggapan kepada kelompok lain.

\section{Observasi Hasil Belajar}

Berdasarkan hasil observasi pada siklus II ditemukan bahwa persentase kegiatan siswa sebesar $46,42 \%$ dan ratarata nilai diperoleh sebesar 86,07. Berdasarkan hasil tes untuk siklus II, diperoleh bahwa kemampuan siswa dalam menulis teks eksplanasi meningkat dari siklus I. Menurut hasil tes siklus II ini diperoleh 28 dari 28 siswa (100,\%) telah mencapai ketuntasan belajar (nilainya $\geq$ 65). Dari 28 siswa terdapat 19 siswa memperoleh nilai $\geq 80$ termasuk siswa dengan tingkat penguasaan sangat baik diantaranya tedapat 8 siswa yang ISSN 15421-71667

\section{Volume 2 Nomor 2 Desember 2019}

memperoleh nilai 95, 9 siswa memperoleh nilai antara 66-80 yang termasuk siswa dengan tingkat penguasaan baik, tidak ditemukan siswa memperoleh nilai antara 51-65 yang termasuk siswa dengan kemampuan cukup, dan tidak ada siswa yang memperoleh nilai $\leq 49$ yang termasuk siswa dengan tingkat penguasaan kurang. Dari hasil tes siklus II ini diperoleh peningkatan ketuntasan belajar sebesar $46,42 \%$, yaitu dari 53,57\% menjadi $100 \%$.

\section{Obsevasi Aktivitas Peneliti (Guru)}

Observasi difokuskan pada kegiatan belajar mengajar yang dilakukan peneliti kedua (guru), khususnya prosedur pengajaran yang menggunakan pembelajaran Problem Based Learning. Dari hasil observasi inilah peneliti akan mengambil keputusan bagi tindakan selanjutnya. hasil observasi aktivitas peneliti kedua (guru), ada beberapa hal yang tidak sempat dilakukan. Namun secara umum kegiatan peneliti kedua (guru) sudah sesuai dengan rencana yang ditetapkan. Maka nilai yang diperoleh dari pengamatan tentang aktifitas guru adalah 36. Sedangkan skor maksimal adalah 40. Dengan demikian persentase nilai rata rata aktivitas peneliti pada siklus II adalah 90\%. Maka taraf keberhasilan peneliti pada siklus II dikategorikan sangat baik.

\section{Obsevasi Aktivitas Siswa}

Berdasarkan hasil dari observasi peserta didik pada tabel pengamatan dalam siklus ini dapat dilihat bahwa secara umum kegiatan sudah sesuai dengan harapan yang dicapai meskipun masih ada beberapa deskriptor yang tidak muncul dalam aktifitas peserta didik selama pembelajaran. Nilai yang diperoleh dari aktifitas peserta didik adalah 45, sedangkan skor maksimal adalah 50 . Sehingga nilai yang diperoleh rata-rata adalah 90 Sesuai kategori keberhasilan yang telah ditetapkan, maka keberhasilan aktifitas peserta didik berada pada kategori yang sangat baik 
Tahap Refleksi II

Berdasarkan hasil observasi, wawancara, dan dari data tes siklus II, berikut ini diuraikan keberhasilan dan kegagalan dalam pelaksanaan tindakan pada siklus II, yaitu:

(a) dari hasil tes yang dilakukan pada siklus II, siswa yang tuntas belajar 28 siswa (100\%), dan tidak ditemukan lagi siswa yang tidak tuntas dengan rata-rata kelas 86,07 sehingga ketuntasan belajar sudah tercapai;

(b) penerapan model pembelajaran Problem Based Learning pada materi menulis teks eksposisi dapat meningkatkan aktivitas guru. Pada pelaklsanaan siklus 1 diperoleh aktifitas peneliti kedua (guru) yaitu $75 \%$ dengan kategori baik. Sedangkan pada siklus II diperoleh aktifitas peneliti kedua (guru) yaitu 90\% dengan dikategorikan sangat baik;

(c) penerapan model pembelajaran Problem Based Learning pada materi menulis teks eksposisi dapat meningkatkan kerjasama peserta didik kelas X-IPS2 SMA Negeri 1 Lumban Julu. Hal ini dapat dibuktikan dengan meningkatnya kerjasama peserta didik yang pada siklus I $75 \%$ yang tergolong pada kategori baik. Kemudian pada siklus II $90 \%$ yang tergolong pada kategori sangat baik. Dengan demikian terbukti bahwa model pembelajaran Problem Based Learning dapat meningkatkan kerjasama peserta didik pada materi menulis teks eksposisi di kelas X-IPS2 SMA Negeri 1 Lumban Julu; dan

(d) penerapan model pembelajaran
Problem Based Learning pada materi menulis teks eksposisi dapat meningkatkan keaktifan belajar peserta didik kelas XIPS2 SMA Negeri 1 Lumban Julu. Hal ini dapat dibuktikan dengan meningkatnya keaktifan belajar pada siklus I 70\% yang tergolong pada kategori baik. Dan pada siklus II aktifitas siswa meningkat menjadi $95 \%$ yang tergolong pada kategori sangat baik. Dengan demikian penerapan model pembelajaran Problem Based Learning dapat meningkatkan aktifitas siswa kelas X-IPS2 SMA Negeri 1 Lumban Julu.

Pelaksanaan pada siklus II ini, secara garis besar berlangsung baik. Karena ketuntasan belajar klasikal sudah tercapai maka model pembelajaran Problem Based Learning berhenti. Dengan demikian diperoleh bahwa pembelajaran dengan model pembelajaran Problem Based Learning dapat meningkatkan kemampuan menulis teks eksposisi siswa. Hal ini tampak dari analisis hasil tes setelah akhir pelaksanaan siklus II. Ketuntasan belajar klasikal pada siklus I 53,57\% meningkat menjadi $100 \%$ pada siklus II, dan ketuntasan belajar klasikal (85\%) sudah tercapai dan melebihi dari yang diharapkan.

\section{PENUTUP}

Berdasarkan penelitian yang telah dilakukan dapat diambil simpulan sebagai berikut:

(1) hasil belajar siswa sebelum penerapan model pembelajaran Problem Based Learning pada materi menulis teks eksposisi tergolong rendah, terbukti dari data tes awal yang diperoleh siswa yaitu: nilai rata-rata tes awal siswa 58,39 dengan persentase ketuntasan belajar 
klasikal 32,14\% jauh di bawah syarat minimal yaitu sebesar $85 \%$;

(2) hasil belajar siswa mengalami peningkatan setelah diterapkan model pembelajaran Problem Based Learning pada materi menulis teks eksposisi. Dapat dilihat dari data hasil belajar pada siklus I, nilai rata-rata siswa meningkat menjadi 68,75 dengan persentase ketuntasan belajar klasikal 53,57\%, sementara pada siklus II nilai rata-rata siswa meningkat menjadi 86,07 dengan persentase ketuntasan belajar klasikal 100\%; dan

(3) Penerapan model pembelajaran Problem Based Learning pada materi menulis teks eksposisi mampu meningkatkan keaktifan siswa selama proses pembelajaran. Hal ini terlihat dari hasil observasi yaitu:

(a) Penerapan model pembelajaran Problem Based Learning pada materi menulis teks eksposisi dapat meningkatkan aktivitas guru. Pada pelaklsanaan siklus 1 diperoleh aktifitas peneliti kedua (guru) yaitu 75\% dengan kategori baik. Sedangkan pada siklus II diperoleh aktifitas peneliti atau guru yaitu 90\% dengan dikategorikan sangat baik;

(b) Penerapan model pembelajaran Problem Based Learning pada materi menulis teks

(c) eksposisi dapat meningkatkan kerjasama peserta didik kelas kelas XIPS2 SMA Negeri 1 Lumban Julu. Hal ini dapat dibuktikan dengan meningkatnya kerjasama peserta didik yang pada siklus I 55,00 \% yang tergolong pada kategori kurang. Kemudian pada siklus II $90,00 \quad \%$ yang tergolong pada kategori sangat baik. Dengan demikian terbukti bahwa strategi pembelajaran small group discussion dapat meningkatkan kerjasama peserta didik pada mata pelajaran PPKn di kelas XI TKP SMK Negeri 1 Bener Meriah; dan

(d) Penerapan model pembelajaran Problem Based Learning pada materi menulis teks eksposisi dapat meningkatkan keaktifan belajar peserta didik kelas XIPS2 SMA Negeri 1 Lumban Julu. Hal ini dapat dibuktikan dengan meningkatnya keaktifan belajar pada siklus I 70\% yang tergolong pada kategori baik. Dan pada siklus II aktifitas siswa meningkat menjadi 95\% yang tergolong pada kategori sangat baik. Dengan demikian penerapan model pembelajaran Problem Based Learning dapat meningkatkan aktifitas siswa kelas X-IPS2 SMA Negeri 1 Lumban Julu.

Berdasarkan penelitian yang telah dilakukan, diajukan saran-saran sebagai berikut:

(1) Guru Bahasa Indonesia diharapkan agar menggunakan model pembelajaran Problem Based Learning sebagai salah satu alternatif untuk meningkatkan kemampuan menulis siswa, khususnya materi menulis teks eksposisi, sehingga dapat meningkatkan 
kualitas proses belajar;

(2) Hendaknya dicoba untuk menerapkan model pembelajaran Problem Based Learning pada materi menulis teks eksposisi; dan

(3) Penelitian selanjutnya dapat berupa pengkombinasian model pembelajaran Problem Based Learning dengan model pembelajaran lainnya agar diperoleh hasil belajar yang lebih baik dan bervariasi.

\section{REFERENSI}

Mulyasa, E, 2005. Menjadi Guru Profesional (Menciptakan Pembelajaran Kreatif dan Menyenangkan)", Bandung: Remaja Rosdakarya

Samsudin, A. (2012). Peningkatan Kemampuan Menulis Eksposisi Berita dan Menulis Eksposisi Ilustrasi Siswa Kelas V Melalui Model

Pembelajaran Kooperatif Terpadu Membaca dan Menulis. Jurnal Penelitian Pendidikan, 13(2), 1-11.

Setyorini, U dkk. 2011. Penerapan Model Problem Based Learning Untuk Meningkatkan Kemampuan Berpikir Kritis Siswa SMP. Jurnal Pendidikan Fisika Indonesia 7 (2011), 52-56.

Urhalinah, dkk. 2018. Penerapan Metode Discovery Learning Pada Pembelajaran Menulis Teks Eksposisi. Jurnal Parole Pendidikan Bahasa dan Sastra Indonesia 1 (6), 1021-1028. wisnu nugroho aji. 2016. Peningkatan Keterampilan Menulis Teks Eksposisi Dengan Metode Inquirydiscovery Learning dan Penggunaan Media Video Pada Siswa Kelas VII G SMP Negeri 3 Colomadu. Jurnal Magistra No. 95.

Maret 2016, 34-42 